\title{
Teacher Salary Differentials and Student Performance: Are They Connected?
}

\author{
Brian D. Yontz (Corresponding author) \\ Department of Education, Wittenberg University \\ P.O. Box 720, Springfield, Ohio 45501, USA
}

Tel: 1-937-327-6403 E-mail: byontz@wittenberg.edu

Rachel E. Wilson

Department of Business and Economics, Wittenberg University

P.O. Box 720, Springfield, Ohio 45501, USA

Tel: 1-937-327-E-mail: wilsonr1@wittenberg.edu

$\begin{array}{lcc}\text { Received: March 10, } 2021 & \text { Accepted: April 2, } 2021 \quad \text { Published: April 19, } 2021 \\ \text { doi:10.5296/jei.v7i1.18400 } & \text { URL: https://doi.org/10.5296/jei.v7i1.18400 }\end{array}$

\begin{abstract}
We examine the relationship between district level student achievement and teacher average salary in Ohio from academic year 2013-14 to academic year 2018-19. Utilizing panel data, the following district level characteristics were controlled for: average teacher experience, average teacher degree-level, student socioeconomic status, race, student attendance rate, pupil support expenditure per equivalent pupil and administration expenditure per equivalent pupil. Using a random effects regression our findings suggest that higher pay can impact student growth. When we partition our sample quintiles by poverty level, we find that teacher salary is only significant for the top quintiles. Our results suggest that for some districts (i.e., wealthy districts) teacher salaries' impact on student performance is something that can be controlled, for other districts (i.e., poorer districts), teacher salary is another variable that shows no relationship to student performance.
\end{abstract}

Keywords: Education economics, Equity, Student performance, Teacher salary

\section{Introduction}

"I wanted to teach," "A fondness for children," "Teaching offers a mean of service to mankind," "Teaching offers an opportunity for reading, study, growth, and work toward a 
college degree," "The teacher is constantly thrown with good refined people," "My brother wished me to become a teacher." These are the most significant factors for becoming a teacher provided by 216 first and second-year women students at the Indiana State Teachers' College from an unpublished study by Charlotte S. Burford in 1930 (Gould, 1934). While the motivators for entering the profession have changed over the past 90 years, we notice two factors that seem to be central to the contemporary conversation of teacher recruitment, retention, and effectiveness - teacher pay and educational outcomes. While the latter seems to become the focus of every significant contemporary American education historical event, (i.e., the launch of Sputnik, the Brown v. Board decision, the publication of A Nation at Risk, the enactment of No Child Left Behind), questions on how compensation is tethered to outcomes doesn't seem to find their way to the public's attention at the same rate.

Visualizing educational outcomes as a return on investing in teacher salary continues to be a complex problem (Hanushek \& Rivkin, 2006; Hanushek, 2016). National analyses are difficult because of the disparate state structures and geographical economic nuances. In addition, multiple teacher characteristics (longevity, degree earned, etc.) which are the typical parameters for public schools' fixed salary schedule shows mixed influence on educational outcomes (Biasi, 2018). Utilizing the National Assessment of Educational Progress (NAEP) tends to be a popular measure when conducting national analyses for various student performance outcomes; however, the sampling and rotating mechanisms of test administration tends to be problematic for analysis of educational outcomes (Darling-Hammond, 2000; Garen \& Bray, 2018). In the U.S., national analyses of student performance are difficult due to disparate state control and expectations and the NAEP is the only assessment that measures what U.S. students know and are able to do. While the NAEP seems to be the best we have in the United States' decentralized public school structure, a state-level analysis will often provide a richer look at impacts of teacher salary on student performance.

In this paper we considered Ohio public school teachers' salaries and their relationship with student performance measures. By analyzing a single state, we can see a bit clearer picture of the return on investment but we recognize the considerable diversity within this single state, especially in the state of Ohio. To address the diversity of teacher and learner, we control for teacher experience, teacher degree level, students' socioeconomic status, students' race, student attendance, pupil support expenditure per equivalent pupil, and administration expenditure per equivalent pupil. These dependent variables help our model while the panel nature of the data allows us to hold constant geographical idiosyncrasies such as the cost of living, the idea of "combat pay" (having to pay a teacher more to work in a complex school district setting), and districts that tend to have high levels of teacher retention and therefore have a higher median salary (Liang, Zhang, Huang, \& Qiao, 2015).

Studying teacher salary is important for school districts and teachers' unions. Numerous studies indicate that the "best and brightest" college students find K-12 public school teaching less attractive than other career options and some researchers indicate that the academic ability of preservice teachers has been declining over time (Ingersoll, Merrill, \& Stuckey, 2014). While voice, autonomy, and time continue to be factors for teacher attrition, 
those concerns are experienced only by those once they enter the profession. The perceived pay discrepancy of public-school teachers further impacts the power to attract the "best and brightest" into the classroom. According to Allegretto and Mishel (2016), the pay penalty of a public-school teachers' weekly wages was $17 \%$ lower than those of comparable workers. This is an increase from a 1.8\% "pay-penalty" in 1994 (Allegretto \& Mishel, 2016). The impact of this increased pay penalty has on attracting those with the greatest potential to be excellent teachers as we know the link between teacher quality and student performance should be considered (Darling-Hammond, 2000; Hanushek (2010); Hanushek (2016).

Positing teacher quality with teacher salary is a complicated endeavor in our country. Chiefly, our public-school teachers are paid on a structured scale and it is rarely possible to increase salaries for effective teachers without increasing salaries for ineffective teachers (Hanushek, 2016). It is more helpful to look at district-level educational outcomes to determine if higher relative pay returns better student performance outcomes.

Occasionally states or districts will attempt to overcome the salary rigidities of a single pay scale with signing bonuses or incentive pay. Liu, Johnson, and Peske (2004) considered the unprecedented \$20,000 signing bonus offered by Massachusetts schools in 1998 in an effort to induce high achievers to enter the profession. Their longitudinal interviews with thirteen of the recipients revealed that the bonuses lacked impact on the recipients' decision to enter the field (Liu et al., 2004). Instead, the interviews uncovered that the program's accelerated route to certification was the true inducement (Liu et al., 2004). Finally, while the bonus was paid out over four years, it was the intrinsic rewards of individual school culture that impacted retention (Liu et al., 2004).

From 2001 to 2014 North Carolina implemented smaller bonus programs in an effort to attract secondary teachers to low performing and/or high poverty in the traditionally undersupplied areas of math, science and special education (Clotfelter, Glennie, Ladd, \& Vigdor, 2008). Survey research showed that the annual salary bonus of $\$ 1,800$ was insufficient to compensate for the more challenging working conditions in disadvantaged schools and therefore did not reduce turnover in the short-time frame it was in place (Clotfelter et al., 2008).

Using a detailed, longitudinal data set on Texas public elementary schools, Hanushek, Kain, and Rivkin (2004) found that salary had a modest effect on teacher mobility once student characteristics such as race and achievement are controlled. Their research concluded that the student characteristics dominate mobility to such an extent that the salary premium necessary to compensate is perhaps as high as $25-40$ percent (Hanushek et al., 2004). As such, they recommend focusing on the working conditions that student characteristics may be proxying for, such as disciplinary problems, poor leadership, or rigid bureaucracy (Hanushek et al., 2004).

Our study adds to the literature by considering observed salary differentials and student performance between districts in Ohio from 2013 to 2017. While our results must be taken with thoughtful care, they provide insights into the nature of district level teacher salary and student performance. 


\section{Theoretical Framework}

Utilizing a systems' change theory, it is important to understand the success and failures of public schooling are influenced by identified variables within the system (the school) but perhaps even more so by elements outside of the system (the home life) (Berliner, 2009). Considerable work has been done to consider the educational effect of both in-system and out-system input variables but identifying and holding these elements constant for analysis of effect is difficult (Berliner, 2009; Greenwald, Hedges, \& Laine, 1996; Hanushek \& Woessmann, 2017). Like any social system, schools can be considered open systems in that the in-school and out-of-school inputs interact to produce an educational output. School leaders and policy makers attempt to maximize the output by controlling, as best they can, the formula and interaction of inputs. Instructional services continue to be the single largest line item within school system budgeting and therefore the largest financial input. Likewise, this budget item, namely the classroom teacher, has been shown to be the best predictor of student educational, social, and economic outcomes (Hanushek, 2010; Jackson, 2016; Sanders, Wright, \& Langevin, 2008).

State determined school funding formulas, existing polices of teachers' employment, a relatively rigid structure of schooling, or as Tyack and Cuban (1995) called the public's perception of "real school," does not easily allow for a simple adjustment of the ratio of instructional services funding (i.e., teacher compensation) to maximize the educational outcomes. Hanushek (2010) noted that alternative individual compensation models (i.e., merit pay, performance pay, etc.) are increasing and are leading to experimental studies of effect size. We recognize the constraints of public schooling structures and while we encourage continual work in various contexts and cases, we think an analysis of the inclusive system writ large (i.e., state-wide), will help continue this analysis and provide opportunities of replication in other states.

\section{Empirical Strategy}

We employ a simple educational production function as the basis of our empirical strategy similar to ones used in the literature (Gottfried, 2014; Hanushek, 1979, 1986; Henderson, Mieszkowski, \& Sauvageau, 1978; Summers \& Wolfe, 1977; Todd \& Wolpin, 2003; Yeung, 2009).

$$
Y_{i T}=\alpha+\beta_{1} X_{i T}+\beta_{2} U_{i T}+\mu_{i T}+\varepsilon_{i T}
$$

In Equation 1, $Y$ is a value-added score for district $i$ in year $T$. Our variable of interest in this study is $X$, which is the natural $\log$ of the district's average salary for teachers. We also include $U$, which is a vector of district level explanatory variables at the district level. Our equation also contains between district effects $(\mu)$ and within district effects $(\varepsilon)$.

We choose the random effects model over a fixed effect model based on the results of the Hausman test. The random effects model helps us to mitigate the likely bias of $\beta_{1}$ that would occur with an ordinary least squares approach. The bias occurs because district salary and value scores are endogenously determined. Thus, if any omitted variables are correlated with the achievement scores and are also correlated with salary level, $\beta_{1}$ will be biased. Perhaps 
some students have both more engaged parents and parents that have purchasing power to geographically select districts with better achievement scores. If we fail to sufficiently control for these unobservable variables, the effect salary on achievement scores will not be isolated. The random effects model addresses this bias is to by controlling for both unobserved time-invariant individual effects and unobserved time-invariant between district effects.

\section{Methods}

The Ohio Department of Education archives a substantial amount of data on public school districts in the state. This rich data source allows us to begin to explore if there is a relationship between teacher pay and student educational outcomes. For our research, we looked at data over a six-year period starting in the school year that began in the fall of 2013 and ending with the school year that began in 2018. We limited our study to 2013 and beyond because our dependent variables of interest are consistently calculated from that point forward. We considered all public-school districts in Ohio except for those that shared services along the border with another state or any with clear data entry errors. Over the six-year period we recorded 3,595 observations. Our key dependent variables were school district scores for progress (Value-Added). The Value-Added metric is an student academic progress model that measures rates of academic growth for students and groups of students from year to year. Research by Chetty, Friedman, and Rockoff (2014) use two novel approaches to show that Value Added measures actually capture causal impacts of teachers rather than reflecting biases caused by student sorting. In Ohio, this measure utilizes aggregated district-level in grades 4-8 in reading and mathematics. Though additional subject areas were added and different tests were used over the interval of the study we utilized the growth model for grades 4-8 in reading and mathematics only. The Value-Added calculation for individual schools and their districts are transposed into a letter grade for easy consumption by the public.

Our independent variable of interest is average teacher salary of each district (Salary). We also control for the following district level variables: average teacher experience (Experience), percentage with a master's degree (Masters), percentage of students classified as impoverished (Economically Disadvantaged), percentage of white students (White), average attendance rate (Attendance), pupil support expenditures per equivalent pupil (Pupil Support) and administrative expenditures per equivalent pupil (Administration). We adjust all dollar variables for inflation to 2013 prices.

Table 1 reports the descriptive statistics on our variables over the six years studied. Our dependent variable, Value-Added, has an average of . 78 which corresponds to a C letter grade. Figure 1 displays density chart Value-Added Score that shows a fairly normal distribution but skewed to the left.

Our key independent variable, Salary, is $\$ 58,292$ over the six-year period with a standard deviation of $\$ 9,252$. There is over a $\$ 94,000$ difference between the minimum and maximum average salary. Figure 2 displays a density chart of Salary in 2013 dollars that shows a fairly normal distribution but skewed to the right. 
Table 1. Descriptive statistics

\begin{tabular}{|l|l|l|l|l|}
\hline & Mean & St. Dev & Min & Max \\
\hline Value Added Score & 0.78 & 9.05 & -75.58 & 61.45 \\
\hline Average Salary & $\$ 58,292$ & $\$ 9,252$ & $\$ 32,622$ & $\$ 127,033$ \\
\hline White (students) & $84.97 \%$ & $18.28 \%$ & $0.00 \%$ & $96.00 \%$ \\
\hline Economically Disadvantaged & $43.61 \%$ & $22.97 \%$ & $0.00 \%$ & $96.00 \%$ \\
\hline Experience (years) & 13.67 & 3.24 & 0.00 & 39.00 \\
\hline Masters (teacher) & $63.57 \%$ & $12.25 \%$ & $4.80 \%$ & $95.40 \%$ \\
\hline Attendance (rate) & $94.90 \%$ & $1.28 \%$ & $86.70 \%$ & $99.60 \%$ \\
\hline Pupil Support & $\$ 505$ & $\$ 203$ & $\$ 90$ & $\$ 1,754$ \\
\hline Administration & $\$ 1,295$ & $\$ 379$ & $\$ 578$ & $\$ 5,791$ \\
\hline
\end{tabular}

Note. 3,595 observations. Dollar amounts adjusted for inflation to 2013 dollars.

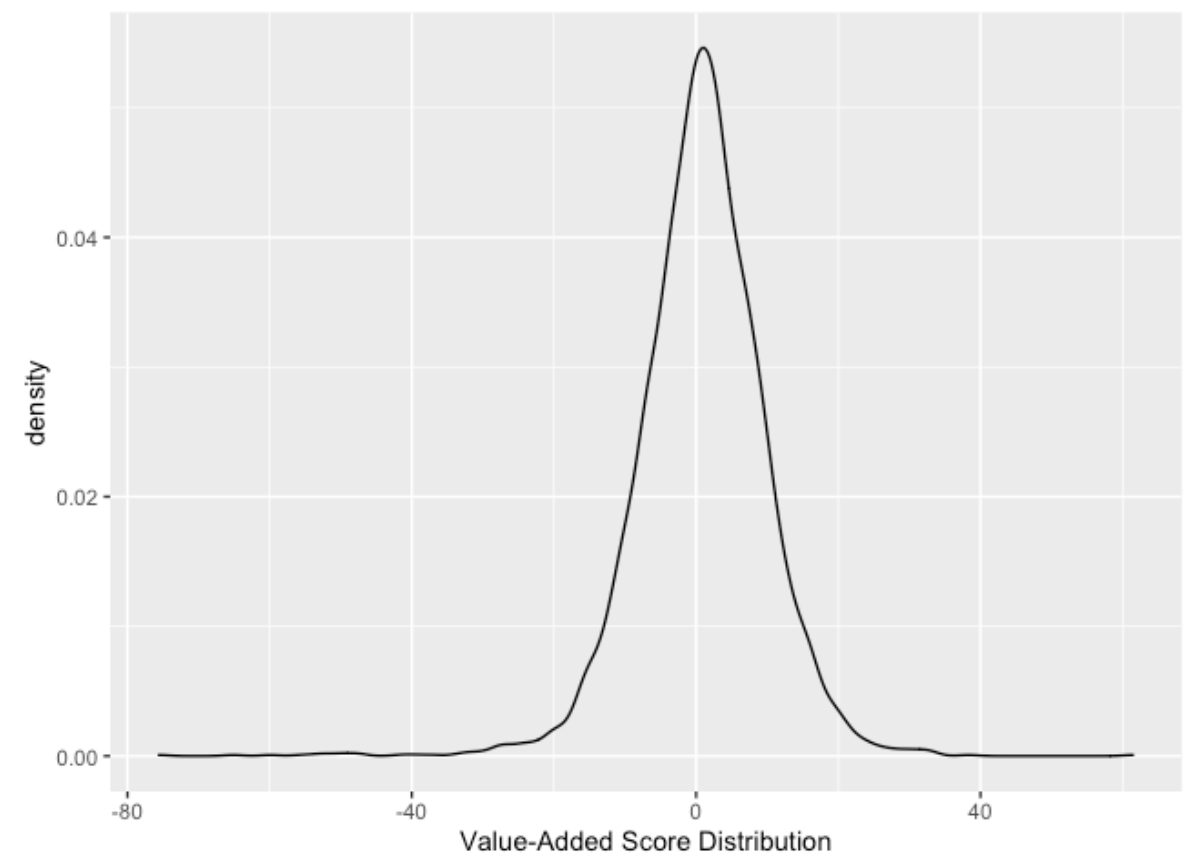

Figure 1. Value-Added Score distribution 


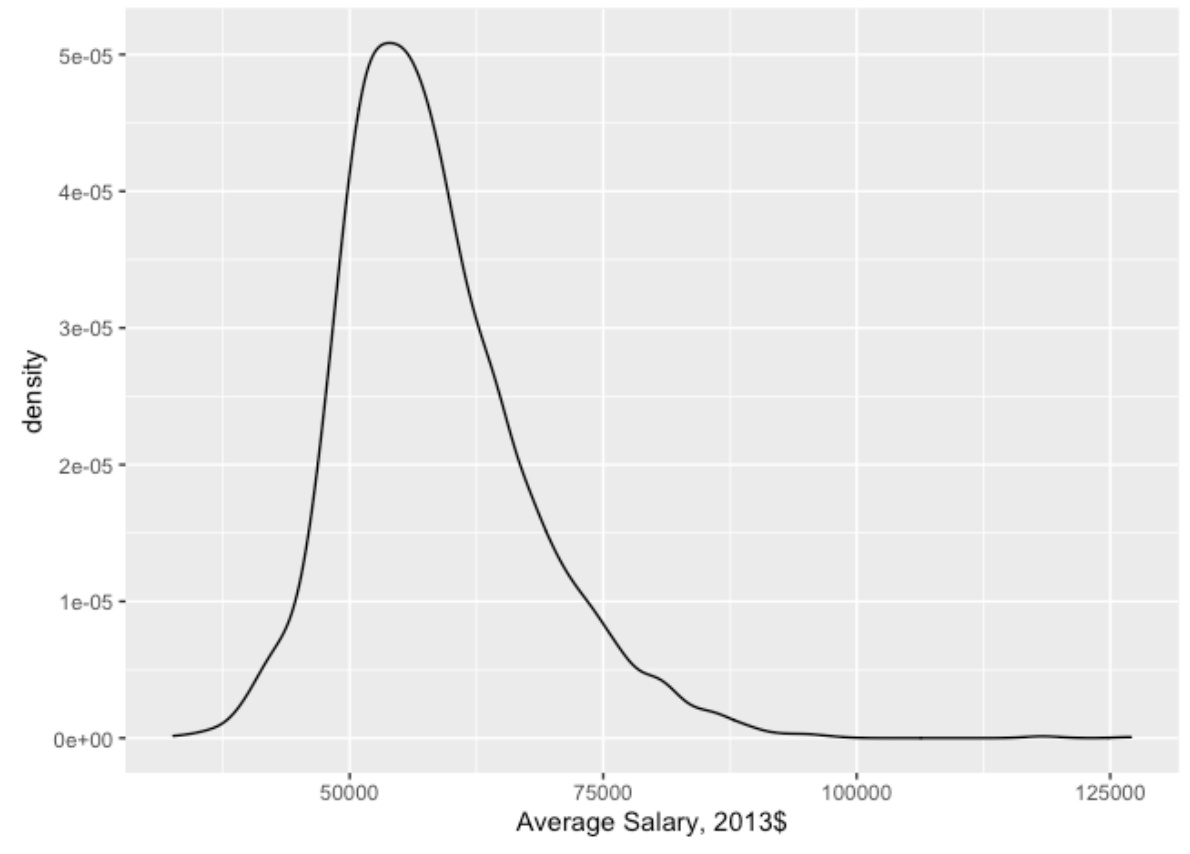

Figure 2. Salary distribution

An advantage of our data is that it is panel data. This allows us to use a random effects regression analysis which controls for time invariant endogeneity. The Hausman test result supports the use of the random effects estimator thus we use random effects estimators in all of our analysis. Table 2 reports the results for 3 models using the full sample. We take the natural log of Salary so that for very small changes, the estimated coefficient of Salary is interpretable as if we increase Salary by one percent the expected change in Value-Added is to change by $\left(\beta_{1} / 100\right)$, holding all other terms constant.

In Model 1, the only explanatory variable is Salary with a statistically significant coefficient of 4.504. Thus, we can interpret it as if Salary increases by $10 \%$, then we would expect on average the Value-Added to increase by 0.45 . Such an increase is $57 \%$ of the sample mean of 0.78 , and only $5 \%$ of the standard deviation. The low R-square of .004 indicates that Salary explains less than half of a percent of the variation in Value-Added.

In model 2 we add school specific controls: Experience, Masters, Pupil Support, Administration. The coefficient on Salary falls almost in half and the significance falls to $10 \%$. The adjusted R-square of this model slightly improves from the first model to 0.013 .

Finally, in Model 3 we add student characteristics as controls: White, Economically Disadvantaged, Attendance. The coefficient on Salary now increases to 5.123 which is larger than Model 1 and its statistical significance rises to $1 \%$. The adjusted R-square also increases to .103 . 
Table 2. Random effects estimator

\begin{tabular}{|l|l|l|l|}
\hline & Model 1 & Model 2 & Model 3 \\
\hline (Intercept) & $-48.589 * * *$ & $-36.105 * *$ & $-205.097 * * *$ \\
\hline & $(13.496)$ & $(15.744)$ & $(30.911)$ \\
\hline Log(Salary) & $4.504 * * *$ & $2.842^{*}$ & $5.128 * * *$ \\
\hline & $(1.238)$ & $(1.509)$ & $(1.445)$ \\
\hline Experience & & 0.029 & -0.059 \\
\hline & & $(0.056)$ & $(0.050)$ \\
\hline Masters & & $0.096 * * *$ & 0.019 \\
\hline & & $(0.017)$ & $(0.017)$ \\
\hline Pupil Support & & 0.000 & 0.001 \\
\hline & & $(0.001)$ & $(0.001)$ \\
\hline Administration & & 0.000 & 0.000 \\
\hline & & $(0.001)$ & $(0.000)$ \\
\hline White & & & $0.049 * * *$ \\
\hline & & 0.013 & $(0.018)$ \\
\hline Economically Disadvantaged & & 3595 & $-0.068 * * *$ \\
\hline Attendance & & & $(0.013)$ \\
\hline & & & $0.553 * * *$ \\
\hline Adj. $\mathbf{R}^{\mathbf{2}}$ & & & 0.106 \\
\hline Num. Obs. & & & 3595 \\
\hline & & & \\
\hline & & & \\
\hline
\end{tabular}

Note. Heteroskedasticity-consistent (White) standard errors below the estimated coefficients, $* * * \mathrm{p}<0.01 ; * * \mathrm{p}<0.05 ; * \mathrm{p}<0.1$.

The literature suggests student poverty, access to early childhood resources, and a limiting of out of school factors are some of the most important determinants of student outcomes (Berliner, 2009; Chetty et al., 2014, McCoy et al., 2017; Michelmore \& Dynarski, 2017). Thus, we partition our sample into quintiles by poverty level and conduct random effects models with each quintile. Table 3 reports the quintiles by the percent of the district economically disadvantaged. 


\section{Macrothink}

Table 3. Distribution of district poverty levels

\begin{tabular}{|l|l|}
\hline Quintile & \% Economically Disadvantaged \\
\hline Poorest & $>58.7$ \\
\hline Second & $58.7 \&>44.7$ \\
\hline Third & $44.7 \&>36.06$ \\
\hline Fourth & $36.06 \&>24.38$ \\
\hline Wealthiest & $<24.38$ \\
\hline
\end{tabular}

Figures 3 and 4 look at our independent and dependent variables by these quintiles. Figure 3 displays a box-plot with individual observations on top of the boxes, using jittering to avoid dot overlap, of Value-Added for each quintile. As a group, the Value-Added observations move to the left as one moves from the wealthiest quintiles to the poorest quintile. The poorest quintile also has the largest number of negative outliers. Figure 4 displays the distributions of Salary by quintile. The wealthiest quintile appears fairly different from the other four quintiles. The mean of wealthiest quintile is clearly to the right of the other quintiles and the right tail is heavy.

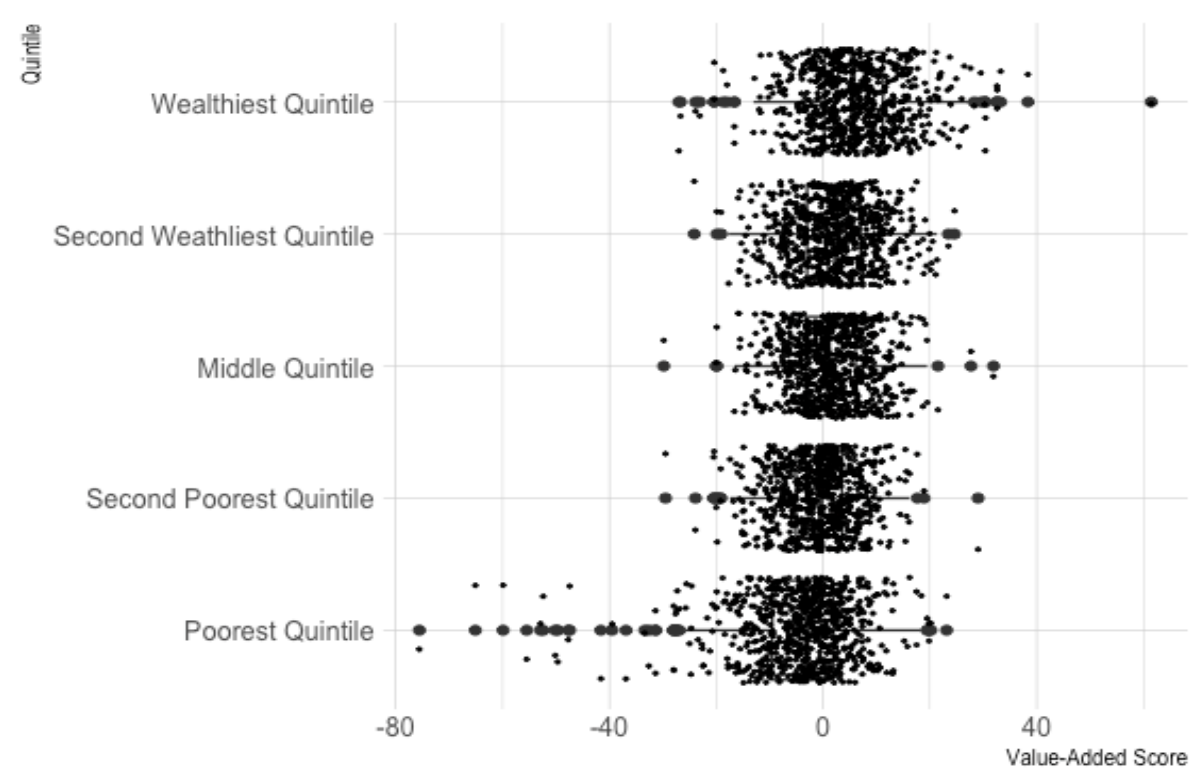

Figure 3. Value-Added levels by quintile 


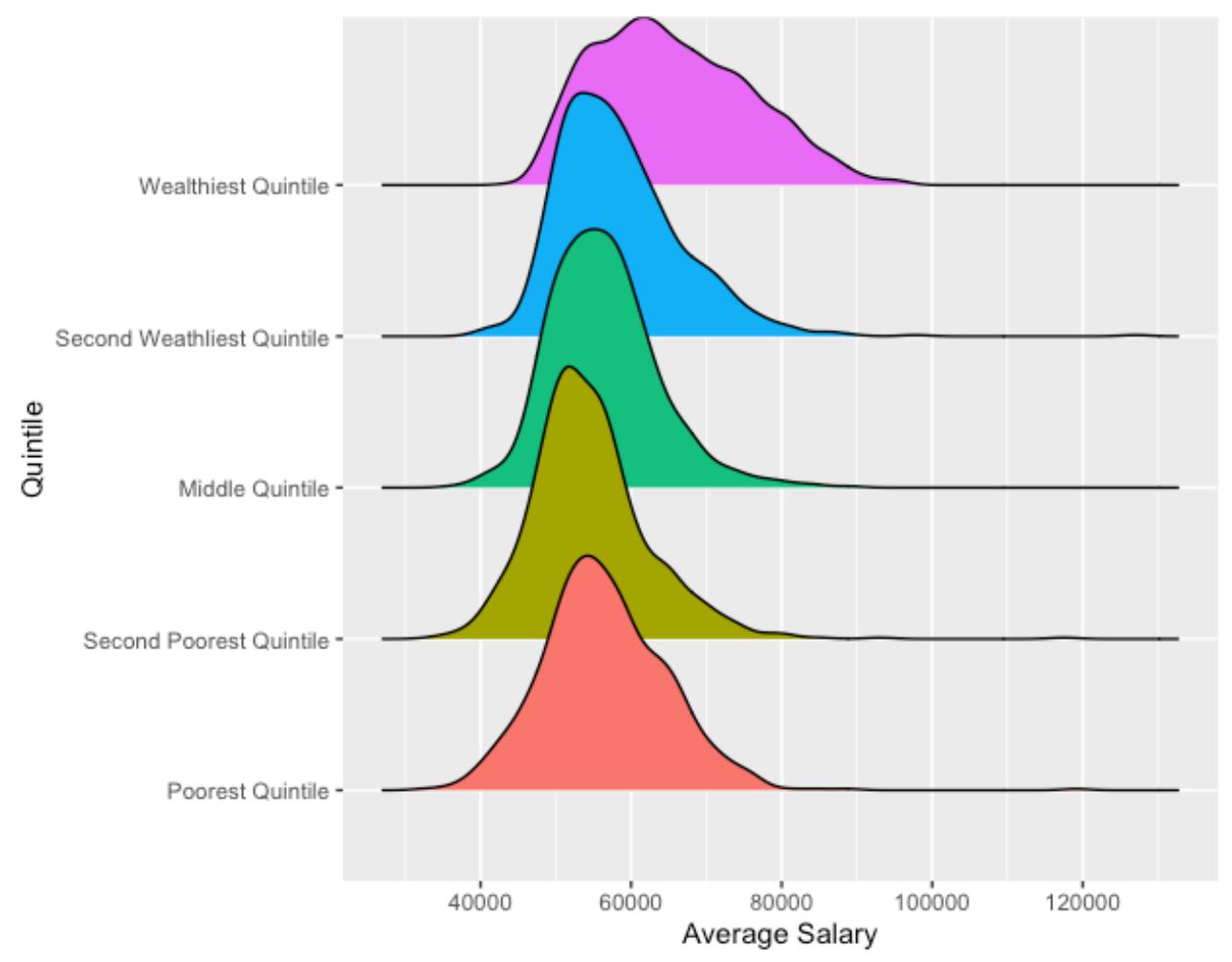

Figure 4. Salary distributions by quintile

Table 4 reports the results of Model 3 by quintile. Salary is not statistically significant for the bottom two quintiles (i.e., the poorest districts). This suggests that if a school district's economically disadvantaged population is greater than $44.7 \%$, increasing salaries has a statistically undetectable impact on Value-Added. The impact of Salary is statistically significant for the other three quintiles and grows larger as quintiles become increasingly wealthier. The results suggest that on average increasing Salary by $10 \%$ increases Value-Added by .65 for the middle quintile, 1.02 for the fourth quintile and 1.23 for the least economically disadvantaged districts. These are all larger than the overall sample estimate displayed in Table 2 . 
Table 4. Random effects regression by quintile

\begin{tabular}{|c|c|c|c|c|c|}
\hline & $\begin{array}{l}\text { Most Economically } \\
\text { Disadvantaged }\end{array}$ & Second & Third & Fourth & $\begin{array}{l}\text { Least Economically } \\
\text { Disadvantaged }\end{array}$ \\
\hline \multirow[t]{2}{*}{ (Intercept) } & $-141.953 * *$ & $-84.131 *$ & $-171.522 * * *$ & $-223.389 * * *$ & $-214.681 * *$ \\
\hline & (70.929) & (49.877) & (59.298) & $(61.823)$ & (87.648) \\
\hline \multirow[t]{2}{*}{ Log(Salary) } & -4.539 & 0.265 & $6.510 * *$ & $10.201 * * *$ & $12.250 * * *$ \\
\hline & $(3.482)$ & $(2.862)$ & (3.103) & $(3.025)$ & (3.716) \\
\hline \multirow[t]{2}{*}{ Experience } & 0.107 & -0.005 & -0.081 & -0.157 & 0.013 \\
\hline & $(0.165)$ & $(0.096)$ & $(0.093)$ & $(0.098)$ & $(0.098)$ \\
\hline \multirow[t]{2}{*}{ Masters } & 0.041 & -0.011 & 0.023 & 0.032 & 0.023 \\
\hline & $(0.042)$ & $(0.028)$ & $(0.034)$ & $(0.034)$ & $(0.039)$ \\
\hline \multirow[t]{2}{*}{ Pupil Support } & -0.003 & -0.002 & 0.001 & 0.001 & 0.003 \\
\hline & $(0.003)$ & $(0.002)$ & $(0.002)$ & $(0.002)$ & $(0.003)$ \\
\hline \multirow[t]{2}{*}{ Administration } & 0.001 & 0.000 & -0.001 & -0.001 & -0.001 \\
\hline & $(0.001)$ & $(0.001)$ & $(0.001)$ & $(0.001)$ & $(0.001)$ \\
\hline \multirow[t]{2}{*}{ White } & 0.031 & $0.047 *$ & 0.023 & 0.070 & -0.078 \\
\hline & $(0.026)$ & $(0.032)$ & $(0.036)$ & $(0.052)$ & $(0.070)$ \\
\hline \multirow[t]{2}{*}{ Economically Disadvantaged } & -0.041 & -0.034 & 0.08 & $-0.300 * * *$ & $-0.146 *$ \\
\hline & $(0.030)$ & $(0.076)$ & $(0.108)$ & $(0.090)$ & $(0.103)$ \\
\hline \multirow[t]{2}{*}{ Attendance } & $1.976 * * *$ & $0.848 * *$ & $1.013 * * *$ & $1.229 * * *$ & 0.963 \\
\hline & $(0.516)$ & $(0.334)$ & $(0.407)$ & $(0.418)$ & $(0.677)$ \\
\hline $\mathbf{R}^{2}$ & 0.107 & 0.026 & 0.016 & 0.053 & 0.068 \\
\hline Adj. $R^{2}$ & 0.097 & 0.015 & 0.005 & 0.043 & 0.057 \\
\hline Num. Obs. & 717 & 723 & 726 & 717 & 712 \\
\hline
\end{tabular}

Note. Heteroskedasticity-consistent (White) standard errors below the estimated coefficients, $* * * \mathrm{p}<0.01 ; * * \mathrm{p}<0.05 ; * \mathrm{p}<0.1$.

As with all studies of teacher salary and educational performance, one major concern is that district performance is endogenously determined with teacher salary. Such endogeneity is most likely to come from simultaneity bias rather than reverse causation. The nature of set teacher salary schedules and widespread prohibitions of pay for performance in Ohio precludes Value-Added causing increases in Salary. However, common sense suggests that Value-Added and Salary are likely to be jointly determined. Our model controls for the most established predictors of Value-Added. In addition, the random effects estimator allows us to control for time invariant omitted variable bias exploiting variation both among institutions and within institutions across time. While this strengthens our results, endogeneity from time 
varying sources may still exist as we do not control for time varying omitted variable bias.

\section{Discussion and Conclusion}

Our study explores the relationship between teacher pay and student performance. For our initial model average salary shows a statistically significant impact on educational outcomes as measured by Value-Added Scores. When we partition our sample by the percent of a district population that is economically disadvantaged, the impact on Value-Added Scores is only statistically significant for the three quintiles of the least economically disadvantaged districts.

While great care should be taken when attempting to generalize our findings outside of the sample we constructed, these findings should be considered especially by both wealthy and poor districts. We suggest that the increase in student growth is seen with an increase in salary in the wealthiest quintiles of school districts. While we recognize an understanding of this relationship as a benefit to wealthy districts, we share the concern for the potential of even greater dichotomy between our wealthy and poor schools. These findings suggest teacher salary is an in-system variable that wealthy districts can control to increase student performance but like many other controlled inputs, the effect does not exist in poor schools. Based on our analysis, small incremental increases teacher salary is an in-school controllable variable without impact in poor districts. Without salary impact, out-of-school factors, those variables that have minimum control by the school, will continue to proliferate with greater effect in poorer districts. This leads us to suggest that these districts should continually consider wrap around services and extended learning opportunities with empirical analysis of their impact.

We also recognize the challenge poor school districts have as it relates to the selection and compensation of their teaching force. We acknowledge geography, working conditions, and student characteristics as reasons why these financially challenged schools often have to incentivize teachers to come and stay, but based on these findings, those financial incentives are not leading to student performance. Figuring out the place of investment is a complex issue for the most complex schools.

Two promising investments in these high-poverty schools are the Restorative Justice School model and the Community School model. The Restorative Justice School model is a comprehensive school approach that shifts culture in ways to prioritize relational pedagogies, justice and equity, resilience-fostering, and well-being (Gregory \& Evans, 2020). Gregory and Evans' (2020) metanalysis of case studies, district-wide correlational studies, and experimental trials convincingly suggest that a restorative school model decreases out-of-school suspension and therefore an increase on in-school learning. To supplement this increase time in-school, high poverty districts should also consider an investment in the Community School model. The Community School model varies in programs offerings however four features that extend the school's interaction with the neighborhood and community typically exist. Most community schools include: 1) integrated student supports with local service providers, 2) expanded learning time and opportunities, 3) family and community engagement with the school and its staff, and 4) collaborative leadership and 
practices (Oakes, Maier, \& Daniel, 2017). Utilizing a community school model provides good promise for targeted and comprehensive interventions in high-poverty schools and aligns with the Every Student Succeeds Act criteria for "evidence-based" interventions (Oakes et al., 2017). While high poverty schools are once again disadvantaged by not being able affect student outcomes by paying teachers more, utilizing a recipe of schooling models that will ensure the "vulnerable are cared for, the marginalized are included, the dignity and humanity of each person in the educational setting matters, and everyone's needs are heard and met" may provide promise for their students' opportunity for good and productive lives (Evans \& Vaandering, 2016, p. 30).

We recognize the reality that even the wealthiest public-school districts don't have the resources to increase teacher compensation on the magnitude that would show changes in growth and achievement noticeable by the public (i.e., moving a full letter grade in Ohio). Likewise, a comprehensive increase in teacher compensation utilizing the prevailing single salary schedule, will uniformly impact effective teachers and ineffective teachers. All districts should carefully consider the pay structure of the current district faculty, the scarcity of some instructional positions, and examine the relationship between effectiveness with longevity and degree earned. Hanushek (2016) reminds us of the reality that our best teachers are likely underpaid and the worst teachers are overpaid and suggests that it is politically infeasible to raise the salaries of the best teachers to an appropriate level. While this is true under our current compensation structure, the conversation around diverse schooling models, the variables that impact educational outcomes, and the magnitude needed to impact these variables, needs to continue. This study helps us think about the control, or lack thereof, some districts have in impacting student performance - even ever so slightly by teacher pay.

\section{References}

Allegretto, S. A., \& Mishel, L. (2016). The teacher pay gap is wider than ever: Teachers' pay continues to fall further behind pay of comparable workers. Washington, DC: Economic Policy Institute. Retrieved from http://www.epi.org/110964

Berliner, D. C. (2009). Poverty and potential: Out-of-school factors and school success. Boulder, CO and Tempe, AZ: Education and the Public Interest Center \& Educational Policy Research. Retrieved from http://epicpolicy.org/publication/poverty-and-potential

Biasi, B. (2018). The labor marker for teachers under different pay schemes (NBER Working Paper 24813).

Chetty, R., Friedman, J. N., \& Rockoff, J. E. (2014). Measuring the impacts of teachers I: Evaluating bias in teacher value-added estimates (NBER Working Paper 19423).

Clotfelter, C. T., Glennie, E. J., Ladd, H. F., \& Vigdor, J. L. (2008). Teacher bonuses and teacher retention in low-performing schools: Evidence from the North Carolina $\$ 1,800$ Teacher Bonus Program. Public Finance Review, 36, 63-87. https://doi.org/10.1177/10911421 06291662

Darling-Hammond, L. (2000). A review of state policy evidence. Education Policy Analysis 
Archives, 8(1), 1-42.

Evans, K. R., \& Vaandering, D. (2016). The little book of restorative justice in education: Fostering responsibility, healing, and hope in schools. Lancaster, PA: Good Books.

Garen, J., \& Bray, R. (2018). Educational test scores, education spending, and productivity in public education: National trends and evidence across states and over time, 1990-2015. SSRN, Rochester, NY. Retrieved from https://ssrn.com/abstract $=3158847$

Gottfried, M. A. (2014). Peer effects in urban schools: Assessing the impact of classroom composition on student achievement. Educational Policy, 28(5), 607-647.

Gould, G. (1934). Motives for entering the teaching profession. The Elementary School Journal, 35(2), 95-102. https://doi.org/10.1086/457136

Greenwald, R., Hedges, L. V., \& Laine, R. D. (1996). The effect of school resources on student achievement. Review of Educational Research, 66(3), 361-396.

Gregory, A., \& Evans, K. R. (2020). The Starts and Stumbles of Restorative Justice in Education: Where Do We Go From Here? Boulder, CO: National Education Policy Center. Retrieved February 4, 2021, from http://nepc.colorado.edu/publication/restorative-justice

Hanushek, E. (1979). Conceptual and empirical issues in the estimation of educational production functions. Journal of Human Resources, 14(3), 351-388. https://doi.org/10.2307/ 145575

Hanushek, E. (1986). The economics of schooling: Production and efficiency in public schools. Journal of Economic Literature, 24(3), 1141-77.

Hanushek, E. A. (2010). The economic value of higher teacher quality. Cambridge, MA: National Bureau of Economic Research. https://doi.org/10.3386/w16606

Hanushek, E. A. (2016). School human capital and teacher salary policies. Journal of Professional Capital and Community, 1(1), 23-40. https://doi.org/10.1108/JPCC-072015-0002

Hanushek, E. A., \& Rivkin, S. G. (2006). Teacher quality. In E. Hanushek, \& F. Welch (eds.), Handbook of the Economics of Education (Vol. 2, pp. 1051-1078). Amsterdam: North Holland.

Hanushek, E. A., \& Woessmann, L. (2017). School resources and student achievement: A review of cross-country economic research. In M. Rosen, K. Y. Hansen, \& U. Wolff (Eds.), Cognitive Abilities and Educational Outcomes (pp. 149-171). Springer.

Hanushek, E. A., Kain, J. F., \& Rivkin, S. G. (2004). Why public schools lose teachers. Journal of Human Resources, 39, 326-354. https://doi.org/10.2307/3559017

Henderson, V., Mieszkowski, P., \& Sauvageau, Y. (1978). Peer group effects and educational production functions. Journal of Public Economics, 10, 97-106.

Ingersoll, R., Merrill, L., \& Stuckey, D. (2014). Seven trends: The transformation of the 
teaching force, updated April 2014 [CPRE Report (\#RR-80)]. Philadelphia: Consortium for Policy Research in Education, University of Pennsylvania.

Jackson, C. K. (2016). What do test scores miss? The importance of teacher effects on non-test score outcomes. Working Paper Series. Chicago: Northwestern Institute for Policy Research. https://doi.org/10.3386/w22226

Liang, G., Zhang, Y., Huang, H., \& Qiao, Z (2015). Teacher incentive pay programs in the United States: Union influence and district characteristics. International Journal of Education Policy \& Leadership, 10(3), 1-18.

Liu, E., Johnson, S. M., \& Peske, H. G. (2004). New teachers and the Massachusetts signing bonus: The limits of inducements. Educational Evaluation and Policy Analysis, 26, 217-236. https://doi.org/10.3102/01623737026003217

McCoy, D. C., Yoshikawa, H., Ziol-Guest, K. M., Duncan, G. J., Schindler, H. S., Magnuson, K., ... Shonkoff, J. P. (2017). Impacts of early childhood education on medium- and long-term educational outcomes. Educational Researcher, 46(8), 474-487. https://doi.org/ 10.3102/0013189X17737739

Michelmore, K., \& Dynarski, S. (2017). The gap within the gap: Using longitudinal data to understand income differences in educational outcomes. AERA Open, 3(1), 1-18. https://doi.org/10.1177/2332858417692958

Oakes, J., Maier, A., \& Daniel, J. (2017). Community Schools: An Evidence Based Strategy for Equitable School Improvement. Boulder, CO: National Education Policy Center. Retrieved February 5, 2021, from http://nepc.colorado.edu/publication/equitable-communityschools

Sanders, W. L., Wright, S. P., \& Langevin, W. E. (2008). Do teacher effect estimates persist when teachers move to schools with different socioeconomic environments? (Working Paper 2008-20). Nashville, TN: National Center on Performance Incentives.

Summers, A. A., \& Wolfe, B. L. (1977). Do schools make a difference? American Economic Review, 67, 639-652. https://doi.org/10.2307/3641209

Todd, P. E., \& Wolpin, K. I. (2003). On the specification of estimation of production function for cognitive achievement. Economic Journal, 113, F3-F33. https://doi.org/10.1111/14680297.00097

Tyack, D., \& Cuban, L. (1995). Tinkering toward utopia: A century of public school reform. Cambridge, MA: Harvard Press.

Yeung, R. (2009). Are school uniforms a good fit? Results from the ECLS-K and the NELS. Educational Policy, 23(6), 847-874. https://doi.org/10.1177/0895904808330170 


\section{Copyright Disclaimer}

Copyright for this article is retained by the author(s), with first publication rights granted to the journal.

This is an open-access article distributed under the terms and conditions of the Creative Commons Attribution license (http://creativecommons.org/licenses/by/3.0/). 